\title{
Acid-base properties of the N3 Ruthenium(II) solar cell sensitizer: A combined experimental and computational analysis
}

\author{
Giuliano Pizzoli, ${ }^{a, b}$ Maria Grazia Lobello, ${ }^{a, b}$ Benedetta Carlotti, ${ }^{a}$ Fausto Elisei, ${ }^{a}$ Mohammad K. Nazeeruddin, ${ }^{c}$ \\ Giuseppe Vitillaro ${ }^{b}$ and Filippo De Angelis ${ }^{b, *}$
}

5

\author{
Received (in $X X X, X X X)$ Xth $X X X X X X X X X 20 X X$, Accepted Xth $X X X X X X X X X 20 X X$ \\ DOI: $10.1039 / b 000000 x$
}

We report a combined spectro-photometric and computational investigation of the acid/base equilibria of the $\mathrm{N} 3$ solar cell sensitizer, $\left[\mathrm{Ru}\left(\mathrm{dcbpyH}_{2}\right)_{2}(\mathrm{NCS})_{2}\right]\left(\mathrm{dcbpyH}_{2}=4,4\right.$ '-dicarboxyl- 2,2' bipyridine) in

10 aqueous/ethanol solutions. The absorption spectra of $\mathrm{N} 3$ recorded at various $\mathrm{pH}$ values were analyzed by Single Value Decomposition techniques, followed by Global Fitting procedures, allowing us to identify four separate acid base equilibria and their corresponding ground state $\mathrm{pK}_{\mathrm{a}}$ values. DFT/TDDFT calculations were performed for the N3 dye in solution, investigating the possible relevant species obtained by sequential deprotonation of the four dye carboxylic groups. TDDFT excited state calculations

15 provided UV-vis absorption spectra which nicely agree with the experimental spectral shapes at various $\mathrm{pH}$. The calculated $\mathrm{pK}_{\mathrm{a}}$ values are also in good agreement with experimental data, within $<1 \mathrm{pK}_{\mathrm{a}}$ unit. Based on the calculated energy differences a tentative assignment of the N3 deprotonation pathway is reported.

\section{Introduction}

\section{${ }_{20}$ A Headings are the primary heading type}

In the last two decades, dye-sensitized solar cells (DSSCs) ${ }^{1,2}$ have attracted a wide interest as potential low-cost photovoltaic systems endowed with high efficiency. In these devices, a dye sensitizer absorbs the solar radiation and transfers the ${ }_{25}$ photoexcited electron to a wide band-gap semiconductor (usually $\mathrm{TiO}_{2}$ ) electrode consisting of a mesoporous oxide layer, while the concomitant hole is transferred to the redox electrolyte, typically iodide/triiodide in solution or a hole-transporting material in the solid state. Recently, the DSSCs field has been revolutionized by

${ }_{30}$ Cobalt-based electrolytes, ${ }^{3}$ which led to a new efficiency record close to $13 \%{ }^{4,5}$

The $\left[\mathrm{Ru}\left(\mathrm{dcbpyH}_{2}\right)_{2}(\mathrm{NCS})_{2}\right]\left(\mathrm{dcbpyH}_{2}=4,4^{\prime}\right.$-dicarboxyl- 2,2' bipyridine) dye and its doubly deprotonated TBA salt, N3 and N719, respectively, have maintained a clear lead in DSSCs 35 technology, with efficiencies exceeding $11 \% .{ }^{6,7}$ For this family of dyes, it was found that the photocurrent obtained from $\mathrm{TiO}_{2}-$ sensitized films decreased when the fully protonated to fully deprotonated dyes were used to dye the semiconductor film. ${ }^{8}$ The DSSCs open circuit voltage, on the other hand, showed an 40 opposite trend, increasing from the fully protonated to the fully deprotonated dye. An optimal product of photocurrent and open circuit voltage was found for an intermediate number of protons, which allowed further device optimization leading to efficiency exceeding $11 \%{ }^{7}$

${ }_{45}$ This marked dependency of the DSSCs performance on acid-base chemistry was attributed to the dye protons, initially residing on the dye carboxylic groups, being released to the $\mathrm{TiO}_{2}$ surface during the sensitization process, thus charging the semiconductor positively. ${ }^{9,10}$ The position of the $\mathrm{TiO}_{2}$ conduction band is known 50 to be dependent from the $\mathrm{pH}$ (it becomes more negative by 0.06 $\mathrm{V}$ for $\mathrm{pH}$ unit increase). ${ }^{11}, 12$ The dependence of the injection kinetics upon protonation of the sensitizer dye most probably thus derives from the influence of protons in determining the potential of the $\mathrm{TiO}_{2}$ conduction band. ${ }^{13}$ Binding of the fully protonated ${ }_{55}$ dye is likely to result in larger proton adsorption to the metal oxide than for the corresponding TBA salts. Indeed, measurements of electron injection rates as function of the $\mathrm{pH}$ of the dye sensitizer solution, demonstrated that the component of ultrafast injection $(<100 \mathrm{fs}$ ) increases upon decreasing the dye ${ }_{60}$ solution $\mathrm{pH}$ from 8 to $2,{ }^{14}$ in relation to the energy down-shift of the $\mathrm{TiO}_{2}$ conduction band.

From an experimental standpoint, information on the semiconductor/dye interfaces is usually accessed by vibrational spectroscopy [Fourier Transform InfraRed (FT-IR) ${ }_{65}$ spectroscopy]. A quantitative analysis of the adsorption mode of $\mathrm{N} 3$ and $\mathrm{N} 719$ sensitizers on $\mathrm{TiO}_{2}$ showed that these dyes anchor onto the $\mathrm{TiO} 2$ surface using two to three of their four carboxylic acid groups. ${ }^{8}, 13,15,16$ The increased open circuit potential observed with the deprotonated dye is, at least in part, the result 70 of the negative shift of the $\mathrm{TiO}_{2}$ conduction band due to adsorption of the anionic dyes, that increases the gap between the 
iodide/triiodide redox couple and the DSSCs quasi-Fermi level under illumination. The decrease in the photocurrent density observed for the fully deprotonated dye compared to that of the fully protonated dye is possibly due to the influence of protons on 5 the energetics of the $\mathrm{TiO}_{2}$ conduction band and therefore on the energetics of electron injection, which depend on the density of acceptor semiconductor states. An alternative reason could be the slower regeneration of the dye by the redox couple because of the decreased driving force between the dye and the redox couple. 10 Indeed, studies of N3 in solution indicated a less positive dye oxidation potential by decreasing the number of dye protons. ${ }^{17}$

Over the years, motivated by the great interest in the photovoltaic applications an increasing number of groups have investigated the acid-base properties of $\mathrm{Ru}(\mathrm{II})$ polypyridyl complexes, including 15 the N3 dye. $\mathrm{pK}_{\mathrm{a}}$ values of 1.85 and 2.90 have been reported for $\mathrm{Ru}(\mathrm{bpy})_{2}(\mathrm{dcbpy})^{2+} \quad\left(\mathrm{bpy}=2,2^{\prime}\right.$ bipyridine, dcbpy $=4,4^{\prime}-$ dicarboxybipyridine), which were related to the concomitant deprotonation of almost equivalent carboxylic groups. ${ }^{18,} 19$ Nazeeruddin et al. $^{20}$ characterized the electrochemical and 20 photochemical properties of several $\mathrm{Ru}(\mathrm{II})$ complexes. In particular they investigated the complexes of the series $\left[\mathrm{Ru}(\mathrm{bpy})_{\mathrm{n}}(\mathrm{dcbpy})^{3-\mathrm{n}}\right] \quad\left(\mathrm{bpy}=2,2^{\prime}\right.$ bipyridine, dcbpy $=4,4^{\prime}$ dicarboxybipyririne, $n=1-3$ ). For $n=1$ they found two $p K a$ values at 1.75 and 2.85 indicating that two carboxylic groups are 25 independent. For $\mathrm{n}=2$ and 3 they found again two $\mathrm{pK}_{\mathrm{a}}$, so they proposed that the dissociation is simultaneous occurring with $1.80-2.50$ and $1.70-2.20 \mathrm{pK}_{\mathrm{a}}$ values, respectively.

Nazeeruddin et al. have then reported two studies regarding two fundamental dyes, i.e. the Black Dye ${ }^{21}$ and N3, ${ }^{22}$ which are 30 amongst the most efficient solar cells sensitizers. In the Black Dye, $\left[\mathrm{Ru}\left(\mathrm{H}_{\mathrm{n}} \mathrm{tcterpy}\right)(\mathrm{NCS})_{3}\right]^{\mathrm{x}-}$ with $\mathrm{n}=3,0$ and $\mathrm{x}=1,4$ (tcterpy $=$ 4,4 ',4' '-tricarboxy-2,2':6',2' '-terpyridine), there are three carboxylic groups on the 4,4 ', 4 ' '-positions of the terpyridine ligand. The titration curves obtained by plotting the absorbance as 35 a function of $\mathrm{pH}$ showed a clear inflection point at $\mathrm{pH}=3.3$ giving the ground state $\mathrm{pK}_{\mathrm{a}}$ value of $3.3 \pm 0.1$. A second inflection point was observed at $\mathrm{pH}$ 5. The $\mathrm{pK}_{\mathrm{a}}$ at 3.3 was assigned to the concurrent dissociation of two protons of the peripheral pyridines, while the second $\mathrm{pK}_{\mathrm{a}}$ value, $\sim 5$, was assigned to the 40 deprotonation of the central pyridine carboxylic group.

In the N3 complex there are four carboxylic groups in two 4,4'dicarboxy-2,2'-bipyridine ligands that could potentially give four separated acid-base equilibria. Nazeeruddin et al. ${ }^{22}$ determined the N3 $\mathrm{pK}_{\mathrm{a}}$ values by UV-Vis spectroscopy measurements. The 45 titration curves showed two inflection points, providing $\mathrm{pK}_{\mathrm{a}}$ values of $3.0 \pm 0.1$ and $1.5 \pm 0.1$ for the concomitant double deprotonation. The observation of two $\mathrm{pK}_{\mathrm{a}}$ values again suggested that there are two separate acid-base equilibria involving the simultaneous dissociation of two protons.

50 Motivated by the established impact of the dye/semiconductor acid-base chemistry interactions in solar cells devices, in this paper we report a joint experimental and computational reinvestigation of the acid-base properties of the $\mathrm{N} 3$ dye. On the experimental side, we report a spectroscopic characterization of 55 the N3 complex with different degrees of protonation and a systematic study of its acid base properties. We have then carried out DFT/TDDFT calculations to extensively investigate the protonation effect of the terminal carboxylic groups, and also computed the $\mathrm{pK}_{\mathrm{a}}$ values to be compared with the experimental ${ }_{60}$ data. Thanks to our combined investigation, we are able to distinguish and tentatively assign the $\mathrm{pK}_{\mathrm{a}} \mathrm{s}$ of the four carboxylic groups of the N3 dye, allowing for a deeper insight into the acidbase properties of this important dye sensitizer.

\section{Experimental section}

\section{${ }_{65}$ 2.1 Chemicals}

The investigated compound N3 was a Solaronix product used without further purification. Ethanol $(\mathrm{EtOH})$ was purchased from Fluka, while nitric acid $\left(\mathrm{HNO}_{3}\right)$ was a Sigma-Aldrich product and $\mathrm{NaNO}_{3}$ salt was furnished by Carlo Erba.

\section{2.2 Photophysical measurements}

Absorption spectra were recorded with a Cary 4E Varian spectrophotometer. A dye stock solution $(\approx 10-5 \mathrm{M})$ was prepared in $1: 1 \mathrm{H}_{2} \mathrm{O} / \mathrm{EtOH}$ mixture containing $0.1 \mathrm{M} \mathrm{NaNO}_{3}$. Ethanol was used to enable compound solubilization in aqueous solution, 75 while $\mathrm{NaNO}_{3}$ keeps the ionic strength constant. The solution $\mathrm{pH}$ was initially adjusted to a value of 12 by addition of $0.2 \mathrm{~N} \mathrm{NaOH}$ and then lowered with concentrated $\mathrm{HNO}_{3}$. Notice that the $\mathrm{pH}$ scale is defined in aqueous solution, so the in mixed waterethanol solutions a different $\mathrm{pH}$ scale is expected. However, the 80 differences in the $\mathrm{pH}$ scale ${ }^{23}$ and consequently in the resulting $\mathrm{pK}_{\mathrm{a}}$ values ${ }^{24}$ are considered marginally significant for the aim of the present work. The UV-vis spectrum of each solution was recorded after adding a negligible acid volume and allowing the solution to equilibrate for 5 minutes. In order to establish the $\mathrm{pK}_{\mathrm{a}}$ 85 of the acid-base equilibria as well as the concentration profiles and the spectra of intermediate species, the global fitting of multivariate spectrophotometric data was carried out by the ReactLab Equilibria software (Jplus Consulting). ${ }^{25}$ The parameters sum-of-squares (ssq) and deviation standard for the 90 residuals $\left(\sigma_{\mathrm{r}}\right)$ were used to evaluate the goodness of the fits. For the analysis of the absorption spectra with a model of four acidbase equilibria, ssq $=0.13$ and $\sigma_{\mathrm{r}}=0.009$ were obtained. Typical experimental errors on the $\mathrm{pK}_{\mathrm{a}}$ values were estimated to be smaller than $\pm 5 \%$.

95

\subsection{Quantum-mechanical calculations}

We investigated the $\left[\mathrm{Ru}(\mathrm{dcbpy})_{2}\left(\mathrm{NCS}_{2}\right)_{2}\right]^{4-} \quad\left(\mathrm{N} 3^{4-}\right)$, $\left[\mathrm{Ru}(\mathrm{dcbpy})(\mathrm{dcbpyH})\left(\mathrm{NCS}_{2}\right)_{2}\right]^{3-}\left(\mathrm{N} 3 \mathrm{H}^{3-}\right),\left[\mathrm{Ru}(\mathrm{dcbpyH})_{2}\left(\mathrm{NCS}_{2}\right)_{2}\right]^{2-}$ $\left(\mathrm{N}_{3} \mathrm{H}_{2}{ }^{2-}\right), \quad\left[\mathrm{Ru}(\mathrm{dcbpyH})\left(\mathrm{dcbpyH}_{2}\right)\left(\mathrm{NCS}_{2}\right)_{2}\right]^{1-} \quad\left(\mathrm{N}_{3} \mathrm{H}_{3}{ }^{-}\right) \quad$ and $100\left[\mathrm{Ru}\left(\mathrm{dcbpyH}_{2}\right)_{2}\left(\mathrm{NCS}_{2}\right)_{2}\right] \quad\left(\mathrm{N}_{3} \mathrm{H}_{4}\right) \quad$ complexes. Following the experimental titration studies, we considered five different protonation states related to the different solutions $\mathrm{pH}$ values. In particular, the optical data, measured in a $\mathrm{pH}$ range 9-0.5, were compared with the nonprotonated species $\left(\mathrm{N}^{4-}\right)$, the 105 monoprotonated $\left(\mathrm{N}^{3} \mathrm{H}^{3-}\right)$, biprotonated $\left(\mathrm{N}_{3} \mathrm{H}_{2}{ }^{2-}\right)$, triprotonated $\left(\mathrm{N}_{3} \mathrm{H}_{3}{ }^{1-}\right)$ and neutral species $\left(\mathrm{N}_{3} \mathrm{H}_{4}\right)$. The $\mathrm{pK}_{\mathrm{a}}$ of an acid HA, defined as $-\log \mathrm{K}_{\mathrm{a}}$, being $\mathrm{K}_{\mathrm{a}}$ the equilibrium constant of the dissociation reaction, is given by the relation $p K_{a}=\Delta G_{a q, H a} / 2.303 R T$. Here, the free energy of deprotonation in 110 water is computed as $\Delta G_{a q, H A}=\Delta G_{g a s, H A}+\Delta \Delta G_{\text {solv }, H A}$, derived from the thermodynamic cycle described in Ref.26. For the proton we adopted values of $-6.28 \mathrm{kcal} / \mathrm{mol}^{27}$ and $-263 \mathrm{kcal} / \mathrm{mol}{ }^{28}$ for the 


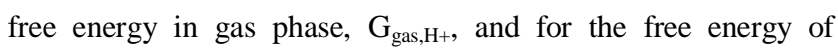
solvation, $\Delta \mathrm{G}_{\mathrm{solv}, \mathrm{H}+}$, respectively. For the calculation of the free energy terms in gas phase $\left(\mathrm{G}_{\mathrm{gas}, \mathrm{HA}}\right.$ and $\left.\mathrm{G}_{\mathrm{gas}, \mathrm{A}-}\right)$, it is necessary to perform single point calculations at the optimized geometries of 5 the protonated and deprotonated species in vacuum, followed by frequency calculations in order to include the vibrational contribution to the total partition function. $\Delta \Delta \mathrm{G}_{\text {isolv }}$ is obtained by single-point calculation in water and reference calculations in gas phase at the optimized geometries in solution. All the calculations 10 were performed using the Gaussian03 $(\mathrm{G} 03)^{29}$ program package. Geometry optimizations of all complexes were performed in vacuum and aqueous solution, using the B3LYP exchangecorrelation functional, ${ }^{30}$ using LANL2DZ basis set ${ }^{31}$ for all atoms along with the corresponding pseudopotentials for Ru. Frequency 15 calculations have been performed at the same level of geometry optimization in gas phase. For the single point calculations in gas phase and in solution we adopted a LANL2DZ basis set and pseudopotential for Ru augmented with a $6-31+\mathrm{G}^{*}$ basis sets ${ }^{32,33}$ for $\mathrm{N}, \mathrm{C}, \mathrm{S}, \mathrm{O}$ and $\mathrm{H}$ atoms. Solvation effects were included by 20 means of the polarizable continuum model (CPCM), ${ }^{34,} 35$ as implemented in G03. To determine the $\mathrm{pK}_{\mathrm{a}}$ values, geometry optimizations were performed in water solution by means of the conductor-like polarizable continuum model (CPCM) using three different options: the default UA0 solvation radii, specific

${ }_{25}$ spheres (SPH) added on the carboxylic hydrogens, and UAHF solvation radii. ${ }^{36}$

The $\mathrm{pKa}$ is then calculated according to the following equation:

$$
p K_{a}=\frac{\left[G\left(A_{g a s}^{-}\right)-G\left(H A_{g a s}\right)+\Delta G_{\text {solv }}\left(A^{-}\right)-\Delta G_{\text {solv }}(H A)-268.37\right]}{1.3644}
$$

TDDFT calculations of the lowest singlet-singlet excitations were 30 performed for all considered species in aqueous solution on the structure optimized in vacuum and using a DGDZVP basis set. To simulate the optical spectra, the 70 lowest spin-allowed singlet-singlet transitions were computed on the ground state geometry. Transition energies and oscillator strengths were 35 interpolated by a Gaussian convolution with an $\sigma$ value of 0.15 $\mathrm{eV}$, corresponding to an FWHM of $\sim 0.4 \mathrm{eV}$.

\section{Results and Discussion}

\subsection{UV-vis Spectroscopic Properties and pKa determination}

40 The UV-vis absorption spectra of $\mathrm{N} 3$ in $1: 1 \mathrm{H}_{2} \mathrm{O} / \mathrm{EtOH}$ mixture (buffered at $\mathrm{pH}=0.5-9$ ) were recorded in the 250-700 $\mathrm{nm}$ range at room temperature (Figure 1). The absorption spectra are characterized by three bands in the investigated region whose position changes significantly with $\mathrm{pH}(\lambda \max \approx 310,370-400$ and ${ }_{45} 510-530 \mathrm{~nm}$, respectively).These bands are typically assigned as $\pi \rightarrow \pi^{*}$ transitions of the bipyridine ligands, and MLCT excitations involving a partial NCS ligand contribution, respectively. ${ }^{37}$ The spectral changes show three quasi isosbestic points at ca. 380, 460 and $515 \mathrm{~nm}$, thus indicating that multiple 50 species contribute to the absorption spectra.

\section{$<$ Figure1 $>$}

Fig.1 Absorption spectra of $\mathrm{N} 3(7.0 \times 10-5 \mathrm{M})$ in $1: 1 \mathrm{H}_{2} \mathrm{O} / \mathrm{EtOH}$ mixture in the $\mathrm{pH}$ range $0.62-7.74$; the arrows show the spectral changes with $\mathrm{pH}$.
In order to characterize quantitatively the N3 acid-base equilibria, 55 the absorption spectra of $\mathrm{N} 3$ recorded at various $\mathrm{pH}$ values were analyzed by SVD analyses followed by Global Fitting procedures. We thus obtained five significant spectral components which describe the experimental data (Figure 2 and Table 1), together with the $\mathrm{pK}_{\mathrm{a}}$ of the associated acid-base 60 equilibria 1-4:

\section{$<$ Scheme1 $>$}

Scheme 1 Acid-base equilibria and $\mathrm{pK}_{\mathrm{a}}$ values of $\mathrm{N} 3$ obtained by SVD Analysis and Global Fitting.

${ }_{65}$ The molar absorption coefficients of the various protonated forms of N3 are also provided by the analysis (Figure 2 and Table 1). The titration curves obtained at relevant wavelengths of analysis (at 385,510 , and $530 \mathrm{~nm}$, where absorbance changes significantly with $\mathrm{pH}$ ) are shown in Figure 3.

\section{$<$ Figure2>}

Fig.2 Quantitative absorption spectra of the protonated forms of N3 in $1: 1 \mathrm{H}_{2} \mathrm{O} / \mathrm{EtOH}$ mixture.

Table 1 Absorption maxima and molar coefficients of the various protonated forms of $\mathrm{N} 3$.

75

$\begin{array}{cll}\text { Compound } & \lambda_{\mathrm{abs}} / \mathrm{nm} & \varepsilon / \mathrm{M}^{-1} \mathrm{~cm}^{-1} \\ \mathrm{~N}^{4-} & 310,375,510 & 51500,13800,13700 \\ \mathrm{~N} 3 \mathrm{H}^{3-} & 310,380,515 & 49700,12900,13400 \\ \mathrm{~N}^{2-} \mathrm{H}_{2}{ }^{2-} & 315,390,525 & 47500,12950,13800 \\ \mathrm{~N}_{3} \mathrm{H}_{3}{ }^{-} & 315,395,530 & 49600,14550,14500 \\ \mathrm{~N} 3 \mathrm{H}_{4} & 305,395,530 & 58700,13400,13400\end{array}$

The obtained $\mathrm{pK}_{\mathrm{a}}$ values were then used to calculate the concentration of each species during the titration experiment. ${ }_{80}$ Figure 4 shows the concentration profiles obtained for the five differently protonated species of $\mathrm{N} 3$. In particular, at $\mathrm{pH}>7$ only the completely deprotonated form is found in solution, while, owing to the close $\mathrm{pK}_{\mathrm{a}} \mathrm{s}$, in acidic solutions at least two species are concomitantly present.

$85 \quad<$ Figure3>

Fig.3 Experimental data (dots) and titration curves (full lines) obtained at relevant wavelengths.

\section{$<$ Figure4 $>$}

90 Fig.4 Concentration profiles of protonated forms of $\mathrm{N} 3$ in 1:1 $\mathrm{H}_{2} \mathrm{O} / \mathrm{EtOH}$ mixture at various $\mathrm{pHs}$.

\subsection{Computational analyses}

\section{Molecular and electronic structures.}

We considered five different protonated form, named $\mathrm{N} 3 \mathrm{H}_{\mathrm{x}}$, with $95 \mathrm{x}=4-0$. For $\mathrm{N}_{3} \mathrm{H}_{2} 2$ - we have four different isomers, named 
$\mathrm{N} 3 \mathrm{H}_{2} 2-\mathrm{A}, \mathrm{N} 3 \mathrm{H}_{2} 2-\mathrm{B}, \mathrm{N} 3 \mathrm{H}_{2} 2-\mathrm{C}$ and $\mathrm{N}_{3} \mathrm{H}_{2} 2-\mathrm{D}$, while for $\mathrm{N} 3 \mathrm{H}_{3}^{-}$and $\mathrm{N} 3 \mathrm{H}^{3-}$ we have two different isomers, $\mathrm{N}_{3} \mathrm{H}_{3}{ }_{-}^{-} \mathrm{A}-\mathrm{B}$ and $\mathrm{N} 3 \mathrm{H}^{3-}$ _A-B, respectively (Figure 5).

$<$ Figure5>

$5 \quad$ Fig.5 Optimized molecular structures of N3Hx complexes.

A schematic orbital energy diagram of the more stable investigated complexes is reported in Figure 6, while isodensity plots of the frontier orbitals of $\mathrm{N}^{4-}$ are shown in Figure 7. A 10 similar study was already reported by some of us, ${ }^{7}$ here we just update this information at the presently employed level of theory and briefly summarize the results. The set of quasi-degenerate HOMO, HOMO-1 and HOMO-2 of all the investigated complexes have essentially $\mathrm{Ru} \mathrm{t}_{2 \mathrm{~g}}$ character. The LUMOs of the 15 complexes are bipyridine $\pi^{*}$ orbitals, with different electronic localization depending on the pronation. The main difference with respect to the protonated species is that the HOMO-LUMO gap increases from 2.49 to $2.88 \mathrm{eV}$, going from $\mathrm{N}_{3} \mathrm{H}_{4}$ to $\mathrm{N}^{4-}$, due to a larger destabilization of the unoccupied with respect to 20 the occupied orbitals. ${ }^{7}$ This is the reason for the observed blueshifted absorption bands with increasing $\mathrm{pH}$.

\section{$<$ Figure6>}

Fig.6 Schematic representation of the energy levels and the molecular 25 structures of the more stable $\mathrm{N}_{3} \mathrm{H}_{\mathrm{x}}$ complexes, considering Gibbs free energies in water solution.

\section{$<$ Figure7>}

Fig.7 Isodensity plots (isodensity value $=0.035$ ) of the HOMOs and LUMOs of $\mathrm{N}^{4-}$ complex.

\section{Acid-base properties}

We simulate now the acid-base properties of the various protonated forms of the $\mathrm{N} 3$ dye. We computed four different $\mathrm{pK}_{\mathrm{a}}$ values with all the investigated solvation models (UA0, SPH and UAHF, see computational details). To tentatively define the 35 stability of different isomers we resort to both Gibbs free energy values employed to calculate the $\mathrm{pK}_{\mathrm{a}} \mathrm{s}$ and the so-called total free energy in solution, from SCF calculations, see Table 2.

${ }_{40}$ Table 2 Relative free energies (including thermal contributions), first line, and solution free energies (from SCF calculations), second line, in water solution of the possible tautomers of $\mathrm{N}_{3} \mathrm{H}_{3}{ }_{-}{ }_{-} \mathrm{A}-\mathrm{B}, \mathrm{N} 3 \mathrm{H}_{2}{ }^{2-}{ }_{-} \mathrm{A}-\mathrm{B}-\mathrm{C}-\mathrm{D}$ and $\mathrm{N} 3 \mathrm{H}^{3-} \_\mathrm{A}-\mathrm{B}$. Energy in $\mathrm{kcal} / \mathrm{mol}$.

$\begin{array}{ccccc} & \text { A } & \text { B } & \text { C } & \text { D } \\ {\mathrm{N} 3 \mathrm{H}_{3}{ }^{-}} & \mathbf{0 . 0 0} & 0.44 & --- & --\end{array}$

\begin{tabular}{|c|c|c|c|c|}
\hline & 0.27 & 0.00 & ---- & --- \\
\hline \multirow[t]{2}{*}{$\mathrm{N} 3 \mathrm{H}_{2}{ }^{2-}$} & 0.00 & 0.42 & 0.19 & 0.83 \\
\hline & 0.82 & 0.35 & 0.58 & 0.00 \\
\hline \multirow[t]{2}{*}{$\mathrm{N} 3 \mathrm{H}^{3-}$} & 0.02 & 0.00 & ---- & --- \\
\hline & 0.00 & 0.09 & ---- & --- \\
\hline
\end{tabular}

Considering the calculated free energies used for the pKa determinations, the species $\mathrm{N}_{3} \mathrm{H}_{3}{ }_{-}^{-} \mathrm{A}$ and $\mathrm{N} 3 \mathrm{H}_{2}{ }^{2-}$-A, see Figure 5, are the most stable tautomers among the species with 3 and 2 50 protons, respectively, while the monoprotonated $\mathrm{N}^{3} \mathrm{H}^{3-} \mathrm{A}_{\mathrm{A}}$ and $\mathrm{N} 3 \mathrm{H}^{3-} \_\mathrm{B}$ species are essentially isoenergetic. By using $\mathrm{SCF}$ energy values, an opposite trend is found. We need to notice, in any case, that the calculated differences are very small so that the assignment of the deprotonation pathway should be considered 55 with some caution.

A summary and comparison of the experimental and computed $\mathrm{pK}_{\mathrm{a}} \mathrm{s}$ involving the most stable tautomers is reported in Table 3. We note that the values obtained using specific spheres (SPH) added on the carboxylic protons provide results which are in ${ }_{60}$ closer agreement with the experimental data, while the default UA0 and the widely employed UAHF solvation radii tend to overestimate the experimental values, Table 3 . On overall, our calculated SPH values agree within 0.31 to 1.06 units of $\mathrm{pK}_{\mathrm{a}}$ with the experimental values. We also notice that the agreement with 65 the experiment tends to decrease by increasing the negative charge of the investigated species, which can be related to the need of explicit solvent effect, e.g. interaction with water molecules, to properly describe the highly negatively charged N3H3- and N34- species. Having in mind the limitations of the 70 model employed, we can draw a deprotonation pathway, see Figure 8.

Table 3 Comparison between experimental and calculated pKas using different computational methods. For calculated pKas the, the lowest values obtained among the various tautomers for each deprotonation step 75 are reported.

$\begin{array}{ccccc} & \text { Exp } & \text { SPH } & \text { UA0 } & \text { UAHF } \\ \mathrm{pK}_{\mathrm{a} 1} & 1.33 & 1.64 & 5.55 & 2.71 \\ \mathrm{pK}_{\mathrm{a} 2} & 2.24 & 2.66 & 6.63 & 4.70 \\ \mathrm{pK}_{\mathrm{a} 3} & 3.45 & 4.37 & 8.35 & 6.62 \\ \mathrm{pK}_{\mathrm{a} 4} & 4.20 & 5.26 & 9.19 & 7.74\end{array}$

\section{$<$ Figure 8>}

Fig.8 Schematic representation of deprotonation path of $\mathrm{N} 3 \mathrm{H} 4$ together with the pKa values calculated by SPH method. are predicted to be those lying on the pyridine ligands cis to the NCS ligands, which are less influenced by the anionic NCS
${ }_{80}$ With reference to Figure 8, we notice that the most acidic protons 
ligands than those in the pyridine ligands trans to the NCS groups. Based on calculate free energies, the second deprotonation should involve the second carboxylic group of the already deprotonated bipyridyne ligand, leading to $\mathrm{N}_{3} \mathrm{H}_{2}{ }^{2-} \_\mathrm{A}$, 5 although deprotonation of the second proton in cis to the NCS groups is found very close in free energy $(0.19 \mathrm{kcal} / \mathrm{mol})$ or favored considered SCF energies. As a matter of fact the NMR spectrum of the N719 salt shows couples of equivalent aromatic signals, ruling out the possibility of the asymmetric structures ${ }_{10} \mathrm{~N}_{3} \mathrm{H}_{2}{ }^{2-} \_$A and $\mathrm{N}_{3} \mathrm{H}_{2}{ }^{2-}{ }_{-} \mathrm{B}$.[7] The different solvent employed and the presence of the tetrabutylamonium counterions might however induce some slight changes in the tautomers stability order. As mentioned above, the performance of the $\mathrm{pK}_{\mathrm{a}}$ calculation tends to decrease, compared to the experimental 15 values, by increasing the negative charges of the species involved in the third and fourth deprotonation steps.

\section{Absorption spectra}

The UV-vis properties of the N3 dye and of its deprotonated 20 forms have been extensively investigated by DFT/TDDFT, ${ }^{7,37-40}$ In this paper, we simulated the absorption spectra of all the considered species to provide a direct connection to the measured UV-vis properties. In order to obtain the global spectrum which might be observed for each species, we calculated the averaged ${ }_{25}$ spectrum, weighted by the respective stabilities, of the different A, B, C and D tautomers, see Supporting Information. In order to reproduce the experimental spectra at various $\mathrm{pH}$ values, we used the concentration profile obtained from the titration experiment. In particular we considered the global spectrum as a sum of 30 contribution of the five species involved in the acid-base equilibria, as reported in equation 1 :

$$
s p e[p H]=\alpha_{p H} 4 H+\beta_{p H} 3 H+\gamma_{p H} 2 H+\delta_{p H} 1 H+\varepsilon_{p H} 0 H
$$

where $\alpha_{\mathrm{pH}}, \beta_{\mathrm{pH}}, \gamma_{\mathrm{pH}}, \delta_{\mathrm{pH}}$ and $\varepsilon_{\mathrm{pH}}$ represent the concentration coefficient at each $\mathrm{pH}$ values, while $4 \mathrm{H}, 3 \mathrm{H}, 2 \mathrm{H}, 1 \mathrm{H}$ and $0 \mathrm{H}$

35 represent the computed spectrum for the different species. The results are reported in Figure 9 for three representative $\mathrm{pH}$ (3.83, 5.35 and 7.74). As it can be noticed, our results are in good agreement with the experimental values, confirming the potential of the employed methodological set-up.

<Figure9>

Fig.9 Comparison between computed (blue line) and experimental (red line) UV-Vis absorption spectra at $\mathrm{pH}=3.83$ (a), 5.35 (b) and 7.74 (c).

\section{Conclusions}

${ }_{45} \mathrm{We}$ have presented a combined experimental and theoretical study on the acid-base properties of the prototypical $\left[\mathrm{Ru}\left(\mathrm{dcbpyH}_{2}\right)_{2}\left(\mathrm{NCS}_{2}\right)_{2}\right] \quad \mathrm{N} 3$ solar cell sensitizer. On the experimental side, the single value decomposition of the absorption spectra measured at various $\mathrm{pH}$ provided a number of 50 five significant spectral components which describe the experimental data, corresponding to four separate $\mathrm{pK}_{\mathrm{a}}$ values. In particular, at $\mathrm{pH}>7$ only the completely deprotonated form is present while, owing to the close $\mathrm{pK}_{\mathrm{a}} \mathrm{s}$, in mildly acidic solutions, at least two differently protonated species are present at the 55 equilibrium. We have then carried out DFT/TDDFT calculations in vacuum and water solution of molecular and electronic structures, optical and acid base properties. The calculated $\mathrm{pK}_{\mathrm{a}}$ values were in excellent agreement with experimental data for the first two deprotonation steps, allowing for a tentative assignment 60 of the deprotonation pathways occurring in the N3 dye. A slight deterioration of the calculated $\mathrm{pK}_{\mathrm{a}} \mathrm{s}$ is found for the subsequent deprotonations, due to the highly negative charge of the involved species. The employed theoretical and experimental approach also allows us to reproduce the N3 UV-vis spectral shape at ${ }_{65}$ different $\mathrm{pH}$ values. We believe this study to constitute a benchmark for the important acid-base properties of $\mathrm{Ru}(\mathrm{II})$ polypyridine solar cells sensitizers.

Acknowledgements GP, BC and FE gratefully acknowledge 70 the financial support of the Ministero per l'Università e la Ricerca Scientifica e Tecnologica (Rome, Italy), the University of Perugia [PRIN 2008, 20088NTBKR] and the Fondazione Cassa di Risparmio di Perugia. MGL, FDA, GV and MKN wish to thank FP7-ENERGY 2010 project "ESCORT", grant agreement 75 261920, and MIUR-PRIN 2008 for financial support.

\section{Notes and references}

${ }^{a}$ Chemistry Department, and Centro di Eccellenza sui Materiali Innovativi Nanostrutturati (CEMIN), University of Perugia, via Elce di 80 Sotto 8, 06123 Perugia, ITALY. Fax: +39-075-5855598; Tel:+39-0755855588;E-mail:elisei@unipg.it

${ }^{b}$ Computational Laboratory for Hybrid/Organic Photovoltaics (CLHYO), Istituto CNR di Scienze e Tecnologie Molecolari Via Elce di Sotto 8, I-06213, Perugia, Italy. Fax+ 390755855606 Tel. +39075585 85 5523.E-mail.filippo@thch.unipg.it

${ }^{c}$ Laboratory of Photonics and Interfaces, Institute of Chemical Science and Engineering, E P F L, CH-1015 Lausanne, Switzerland.

$\dagger$ Electronic Supplementary Information (ESI) available: Molecular 90 orbitals energy, absorption spectra in water solution and computed $\mathrm{pK}_{\mathrm{a}}$ values. See DOI: $10.1039 / \mathrm{b} 000000 \mathrm{x} /$

1. B. O'Regan and M. Grätzel, Nature, 1991, 353, 737.

2. M. Grätzel, Inorg. Chem., 2005, 44, 6841.

95 3. S. M. Feldt, E. A. Gibson, E. Gabrielsson, L. Sun, G. Boschloo and A. Hagfeldt, J. Am. Chem. Soc., 2010, 132, 16714.

4. A. Yella, H.-W. Lee, H. N. Tsao, C. Yi, A. K. Chandiran, M. K. Nazeeruddin, E. W.-G. Diau, C.-Y. Yeh, S. M. Zakeeruddin and M. Grätzel, Science, 2011, 334, 629.

100 5. J.-H. Yum, E. Baranoff, F. Kessler, T. Moehl, S. Ahmad, T. Bessho, A. Marchioro, E. Ghadiri, J.-E. Moser, C. Yi, M. K. Nazeeruddin and M. Grätzel, Nat Commun, 2012, 3, 631.

6. M. K. Nazeeruddin, A. Kay, I. Rodicio, R. Humphry-Baker, E. Mueller, P. Liska, N. Vlachopoulos and M. Grätzel, J. Am. $105 \quad$ Chem. Soc., 1993, 115, 6382.

7. M. K. Nazeeruddin, F. De Angelis, S. Fantacci, A. Selloni, G. Viscardi, P. Liska, S. Ito, B. Takeru and M. Grätzel, J. Am. Chem. Soc., 2005, 127, 16835.

8. M. K. Nazeeruddin, R. Humphry-Baker, P. Liska and M. Grätzel, $J$. $110 \quad$ Phys. Chem. B, 2003, 107, 8981 . 
9. Y. Tachibana, M. K. Nazeeruddin, M. Grätzel, D. R. Klug and J. R. Durrant, Chem. Phys., 2002, 285, 127.

10. F. De Angelis, S. Fantacci, A. Selloni, M. K. Nazeeruddin and M. Grätzel, J. Am. Chem. Soc., 2007, 129, 14156.

5 11. G. Rothenberger, D. Fitzmaurice and M. Grätzel, J. Phys. Chem., 1992, 96, 5983.

12. G. Redmond and D. Fitzmaurice, J. Phys. Chem., 1993, 97, 1426.

13. F. De Angelis, S. Fantacci, A. Selloni, M. Grätzel and M. K. Nazeeruddin, Nano Lett., 2007, 7, 3189.

10 14. J. B. Asbury, N. A. Anderson, E. Hao, X. Ai and T. Lian, J. Phys. Chem. B, 2003, 107, 7376.

15. K. E. Lee, M. A. Gomez, S. Elouatik and G. P. Demopoulos, Langmuir, 2010, 26, 9575.

16. K. E. Lee, M. A. Gomez, S. Elouatik, G. B. Shan and G. P.

15 Demopoulos, J. Electrochem. Soc., 2011, 158, H708.

17. G. Wolfbauer, A. M. Bond, G. B. Deacon, D. R. MacFarlane and L. Spiccia, J. Am. Chem. Soc., 1999, 122, 130.

18. P. J. Giordano, C. R. Bock, M. S. Wrighton, L. V. Interrante and R. F. X. Williams, J. Am. Chem. Soc., 1977, 99, 3187.

20 19. T. Shimidzu, T. Iyoda and K. Izaki, J. Phys. Chem., 1985, 89, 642.

20. M. K. Nazeeruddin and K. Kalyanasundaram, Inorg. Chem., 1989, 28, 4251 .

21. M. K. Nazeeruddin, P. Pèchy, T. Renouard, S. M. Zakeeruddin, R. Humphry-Baker, P. Comte, P. Liska, L. Cevey, E. Costa, V.

25 Shklover, L. Spiccia, G. B. Deacon, C. A. Bignozzi and M. Grätzel, J. Am. Chem. Soc., 2001, 123, 1613.

22. M. K. Nazeeruddin, S. M. Zakeeruddin, R. Humphry-Baker, M. Jirousek, P. Liska, N. Vlachopoulos, V. Shklover, C.-H. Fischer and M. Grätzel, Inorg. Chem., 1999, 38, 6298.

30 23. R. G. Bates, M. Paabo and R. A. Robinson, J. Phys. Chem., 1963, 67, 1833.

24. A. Avdeef, K. J. Box, J. E. A. Comer, M. Gilges, M. Hadley, C. Hibbert, W. Patterson and K. Y. Tam, J. Pharmaceut. Biomed. Anal., 1999, 20, 631.

35 25. B. Carlotti, A. Cesaretti and F. Elisei, Phys. Chem. Chem. Phys., 2012, 14, 823 .

26. G. A. A. Saracino, R. Improta and V. Barone, Chem. Phys. Lett., 2003, 373, 411.

27. I. A. Topol, G. J. Tawa, S. K. Burt and A. A. Rashin, J. Chem. Phys., $40 \quad$ 1999, 111, 10998.

28. M. D. Tissandier, K. A. Cowen, W. Y. Feng, E. Gundlach, M. H. Cohen, A. D. Earhart, J. V. Coe and T. R. Tuttle, J. Phys. Chem. A, 1998, 102, 7787.

29. M. J. T. Frisch, G. W.; Schlegel, H. B.; Scuseria, G. E.; M. A. C. Robb, J. R.; Montgomery, J. A., Jr.; Vreven, T.; K. N. B. Kudin, J. C.; Millam, J. M.; Iyengar, S. S.; Tomasi, J.;, V. M. Barone, B.; Cossi, M.; Scalmani, G.; Rega, N.; Petersson,, H. H. G. A.; Nakatsuji, M.; Ehara, M.; Toyota, K.; Fukuda, R.; J. I. Hasegawa, M.; Nakajima, T.; Honda, Y.; Kitao, O.; Nakai, H.; M. L. Klene, X.; Knox, J. E.; Hratchian, H. P.; Cross, J. B.; Bakken, V.; C. J. Adamo, J.; Gomperts, R.; Stratmann, R. E.; Yazyev, O.; A. J. C. Austin, R.; Pomelli, C.; Ochterski, J. W.; Ayala, P. Y.; K. V. Morokuma, G. A.; Salvador, P.; Dannenberg, J. J.; Zakrzewski,, S. D. V. G.; Dapprich, A. D.; Strain, M. C.; Farkas, O.; Malick, D., A. D. R. K.; Rabuck, K.; Foresman, J. B.; Ortiz, J. V.; Cui, Q.;, A. G. C. Baboul, S.;
Cioslowski, J.; Stefanov, B. B.; Liu, G.; Liashenko, A.; Piskorz, P.; Komaromi, I.; Martin, R. L.; Fox, D. J.; Keith,, M. A. P. T.; Al-Laham, C. Y.; Nanayakkara, A.; Challacombe, M.; P. M. W. J. Gill, B.; Chen, W.; Wong, M. W.; Gonzalez, and J. A. C.; Pople, Gaussian 03, Revision C.02. Gaussian, Inc., Wallingford, CT, , (2004).

30. A. D. Becke, J. Chem. Phys., 1993, 98, 5648.

31. P. J. Hay and R. W. Willard, J. Chem. Phys., 1985, 82, 299.

65 32. V. A. Rassolov, M. A. Ratner, J. A. Pople, P. C. Redfern and L. A. Curtiss, J. Comput. Chem., 2001, 22, 976.

33. A. R. Vitaly, A. P. John, A. R. Mark and L. W. Theresa, J. Chem. Phys., 1998, 109, 1223.

34. E. S. S. Miertš, J. Tomasi, Chem. Phys., 1981, 55, 117-169.

70 35. V. B. M. Cossi, R. Cammi, J. Tomasi, Chem. Phys. Lett. , 1996, 255, 327.

36. V. Barone, M. Cossi and J. Tomasi, J. Chem. Phys., 1997, 107, 3210.

37. S. Fantacci, F. De Angelis and A. Selloni, J. Am. Chem. Soc., 2003, 125, 4381.

75 38. F. De Angelis, S. Fantacci and A. Selloni, Chem. Phys. Lett., 2004, 389, 204.

39. F. De Angelis, S. Fantacci, A. Selloni and M. K. Nazeeruddin, Chem. Phys. Lett., 2005, 415, 115.

40. J. E. Monat, J. H. Rodriguez and J. K. McCusker, J. Phys. Chem. A, 2002, 106, 7399 . 


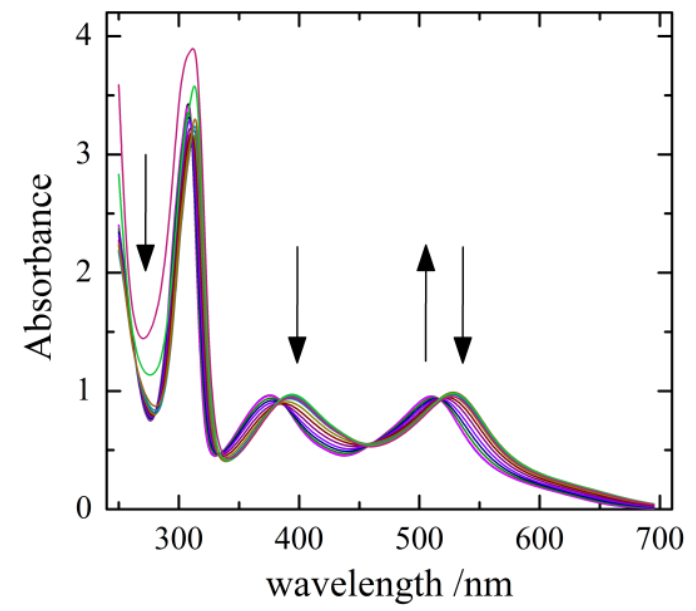

Fig.1 


$$
\begin{aligned}
& \mathrm{N} 3 \mathrm{H}_{4} \rightleftarrows N \mathrm{~N}_{3}+H^{+} \text {(1) } p K_{a 1}=1.33 \\
& \mathrm{~N} 3 \mathrm{H}_{3} \rightleftarrows \mathrm{N} 3 \mathrm{H}_{2}^{2}+H^{+} \text {(2) } p K_{a 2}=2.24 \\
& \mathrm{~N} 3 \mathrm{H}_{2}^{2} \rightleftarrows \mathrm{N} 3 \mathrm{H}^{3}+H^{+} \text {(3) } p K_{a 3}=3.45 \\
& \mathrm{~N} 3 \mathrm{H}^{3} \rightleftarrows \mathrm{N}^{4}+H^{+} \text {(4) } p K_{a 4}=4.20
\end{aligned}
$$




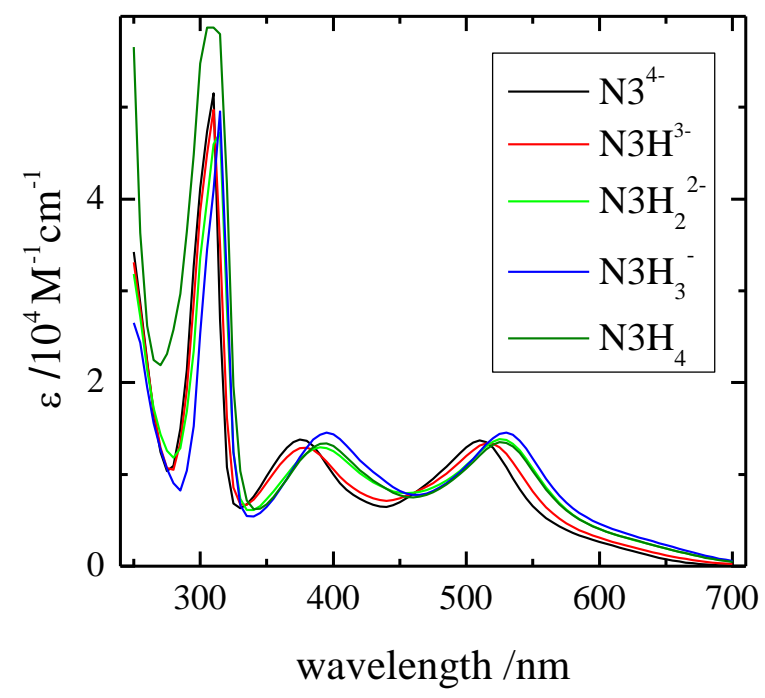

Fig.2 


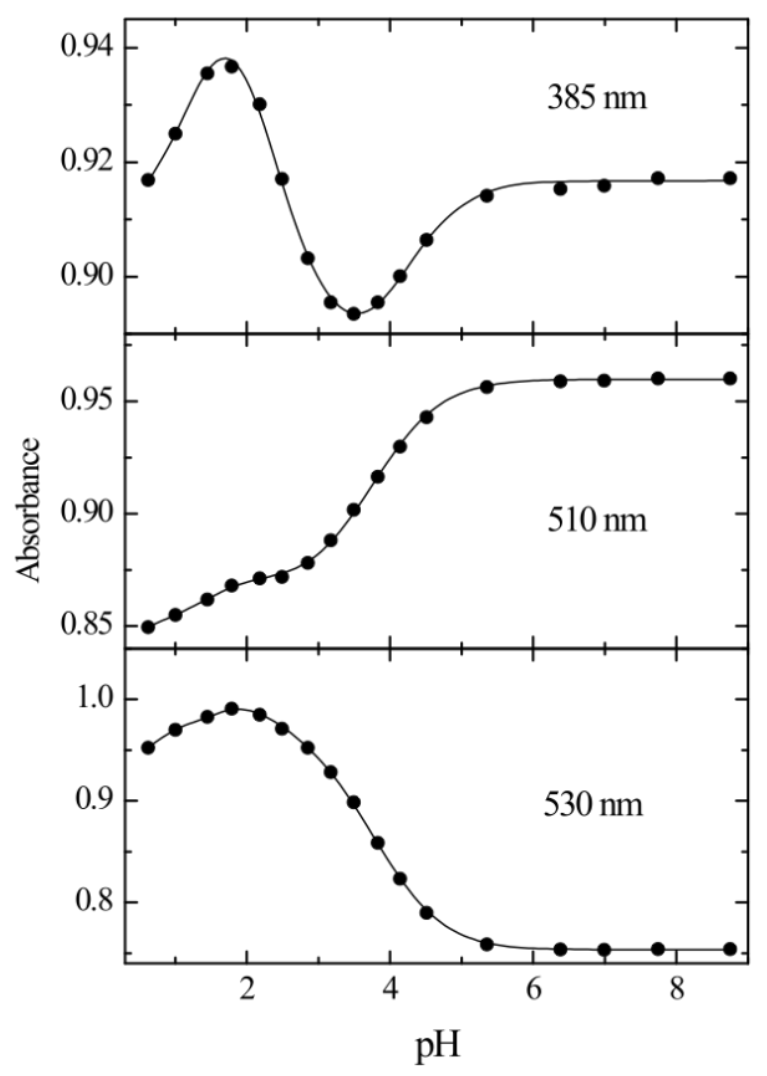

Fig.3 


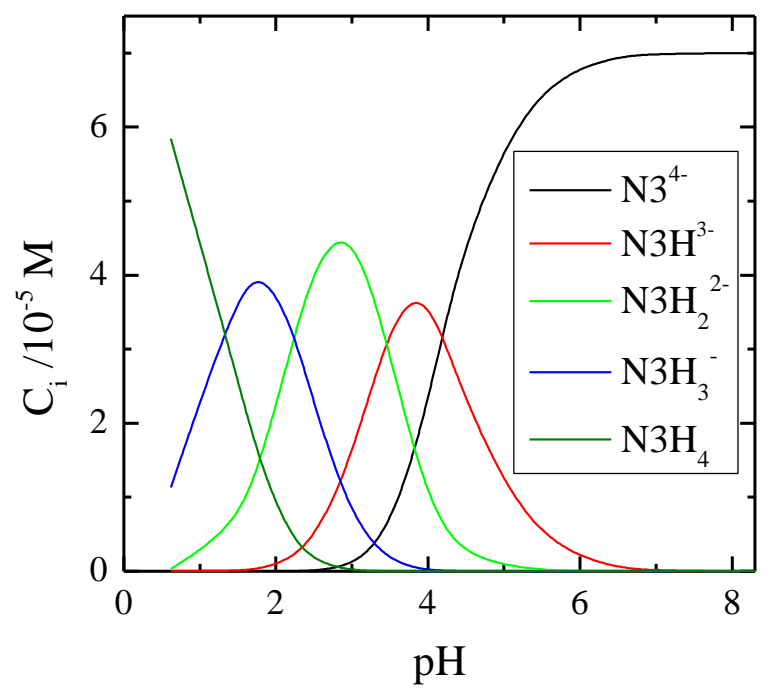

Fig. 4 


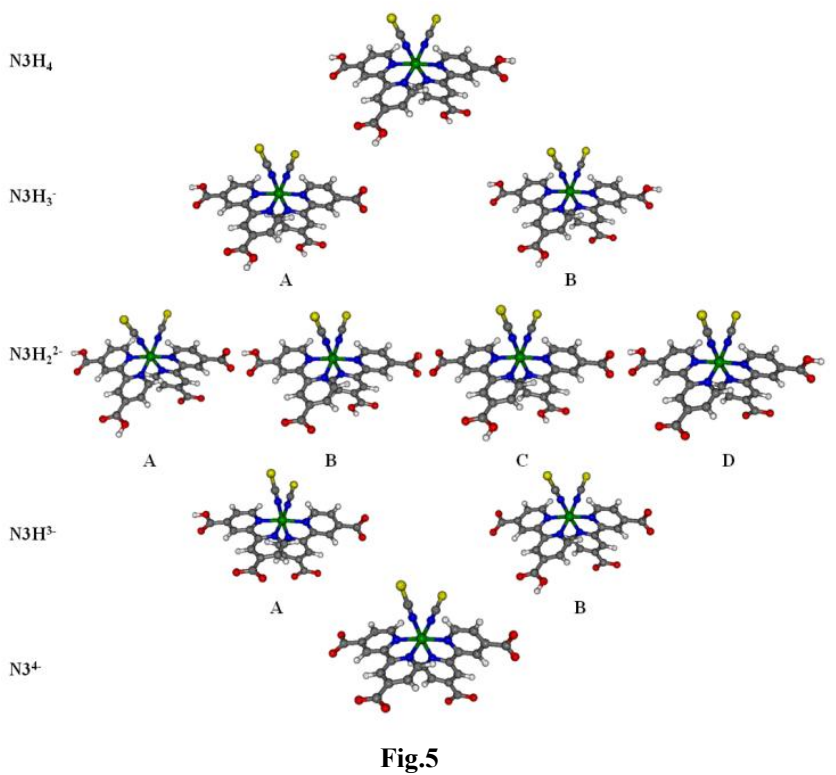




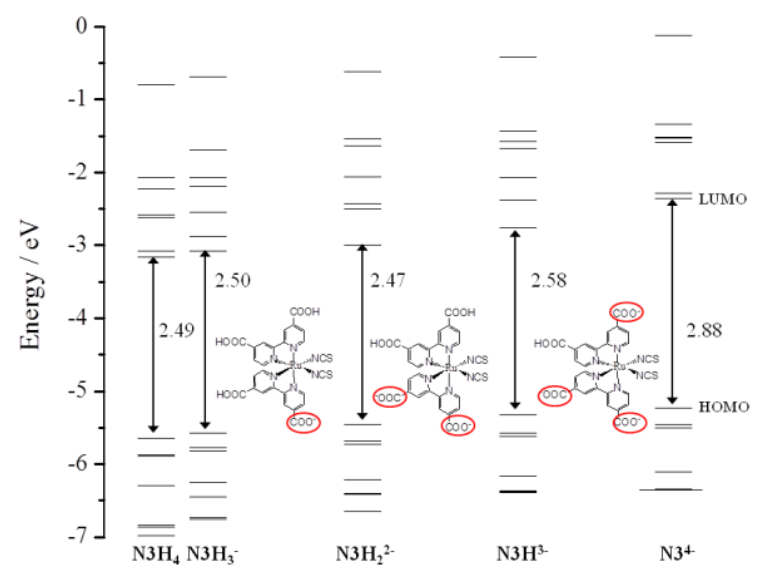

Fig.6

5 

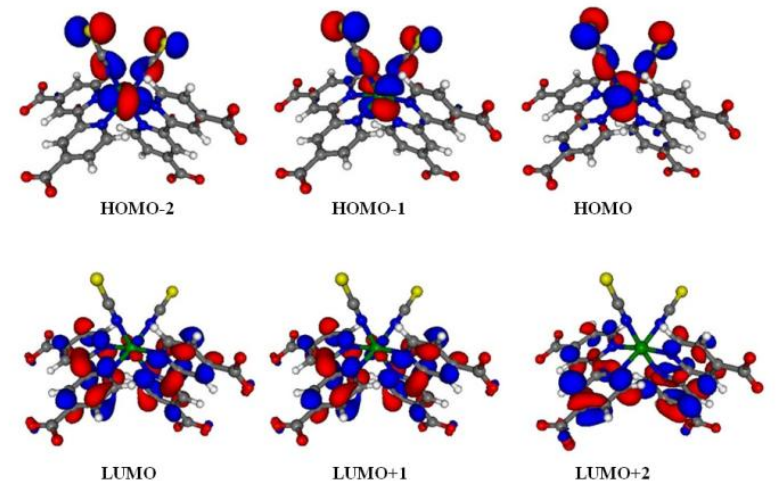

Fig. 7 


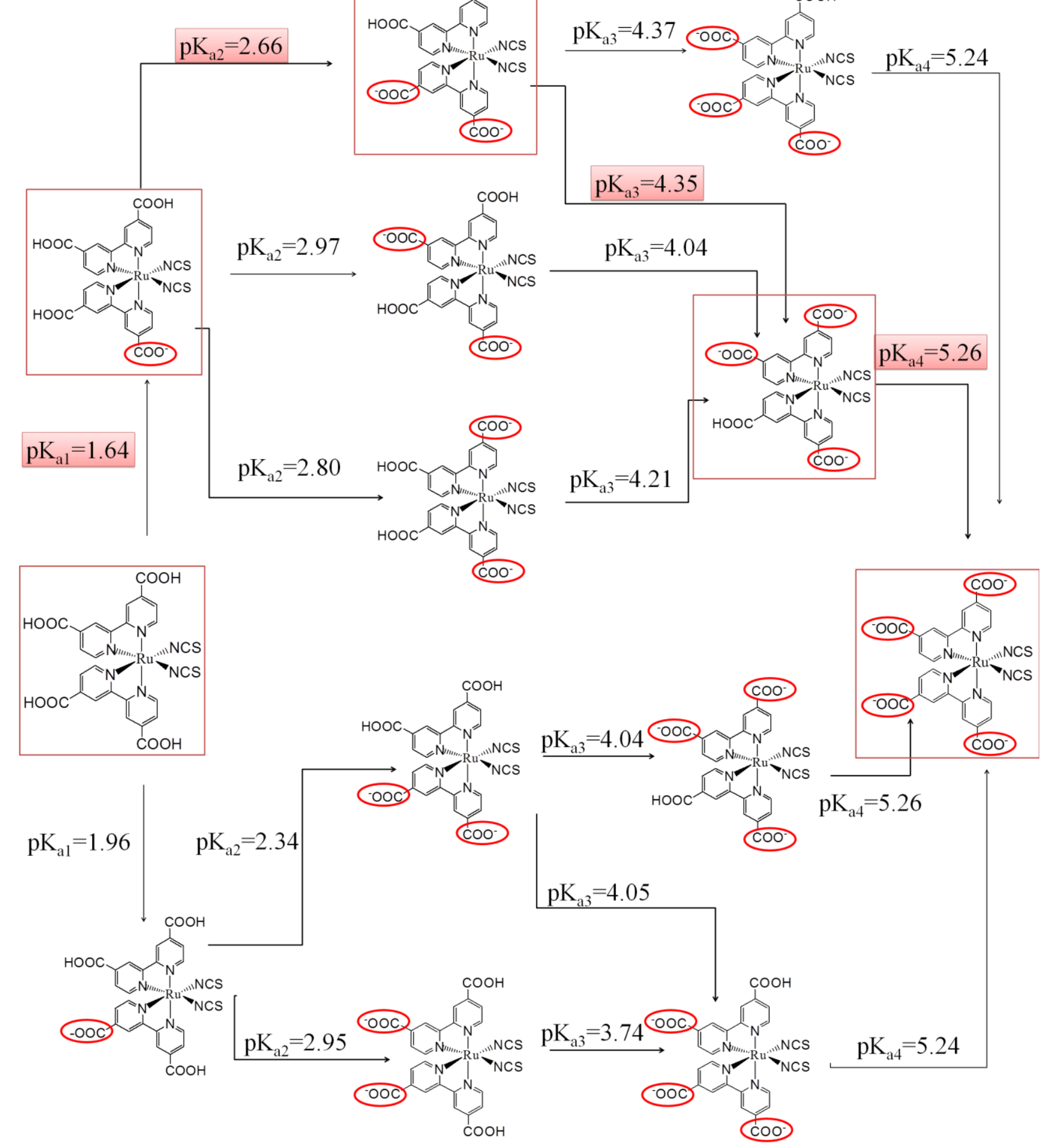

Fig. 8 

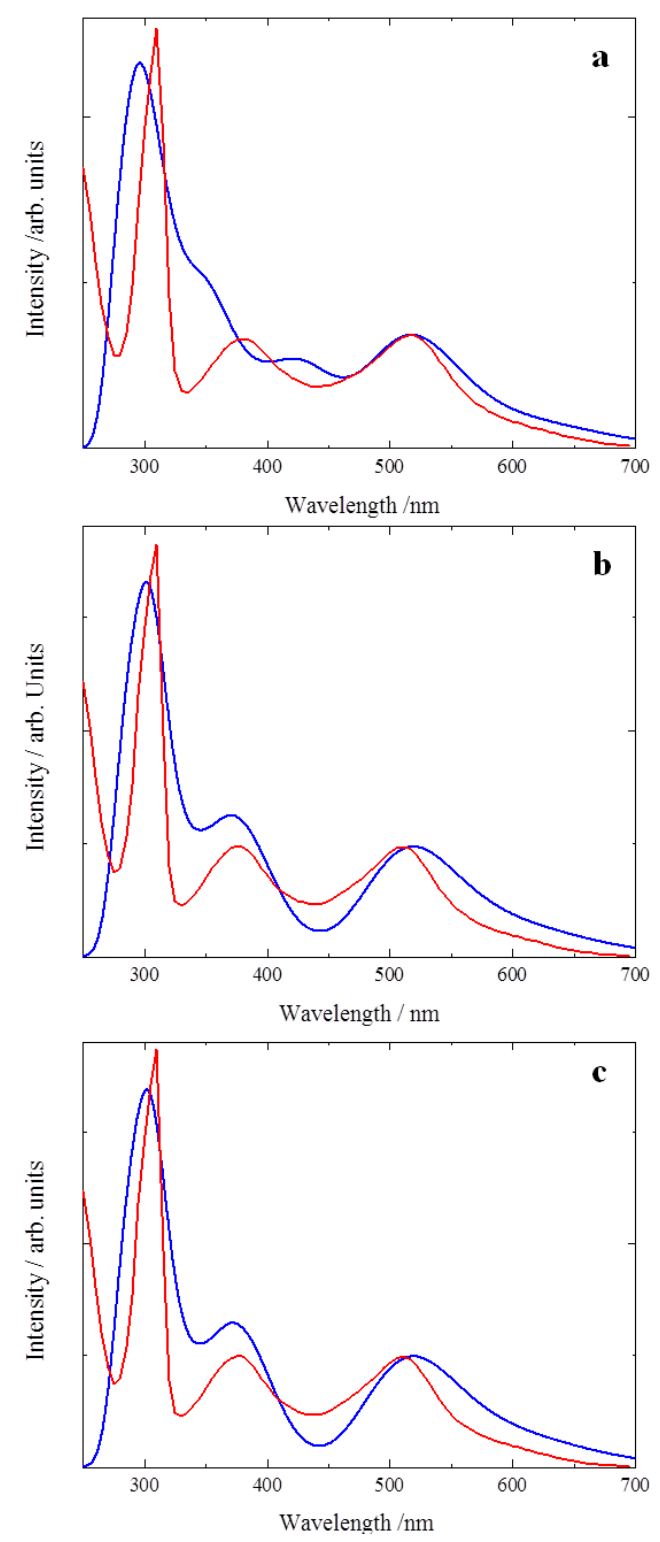

Fig.9 